\title{
How Is Our Future Climate Projected?'
}

\author{
Young Gu Her, Zachary Brym, Ashley Smyth, and Elias Bassil ${ }^{2}$
}

\section{Introduction}

Climate is the long-term patterns and fluctuations in air and moisture. It interacts with everything on Earth's surface. Climate influences plants, animals, humans and their behavior patterns, and evolution. In turn, biological organisms can also contribute to the climate system at varying spatiotemporal scales. Scientific terminology associated with determining the future climate has become ubiquitous. It is important to understand terms used to describe potential future changes in climate and the probable impacts of these changes on our daily lives (Darby 2015; Harvey 2015). This article explains how future climate is projected using mathematical models and introduces common scientific terms used when discussing climate change. This article aims to help increase public awareness of climate change and aid in discussions among scientists, decision makers, and concerned residents.

\section{What is climate?}

Climate is long-term average weather, characterized by many factors including air temperature, precipitation, wind direction, and humidity. The variability in these physical features is expressed as weather and emerges as climate over long time periods such as years, decades, and beyond (NOAA 2019; NASA 2019). Climate changes slowly over decades and centuries due to natural processes including volcanic activity and human activities such as greenhouse gas emission (Figure 1). The climate of an area is determined by not only latitude but also elevation, topography, vegetation, land uses, proximity to the ocean, and ocean currents, all of which can make areas located at the same latitude exhibit different climate features. For instance, Florida's climate is temperate and tropical, but Libya is mostly in a hot desert, even though they are located in similar latitude ranges (Florida lies between $24.5^{\circ} \mathrm{N}$ and $31^{\circ} \mathrm{N}$, and Libya is between $19.5^{\circ} \mathrm{N}$ and $33^{\circ} \mathrm{N}$ ). At large scales, astronomical factors, including solar variability and oscillations in the Earth's axis of rotation (sometimes called external forcing), cause climate to change (NRC 1982).

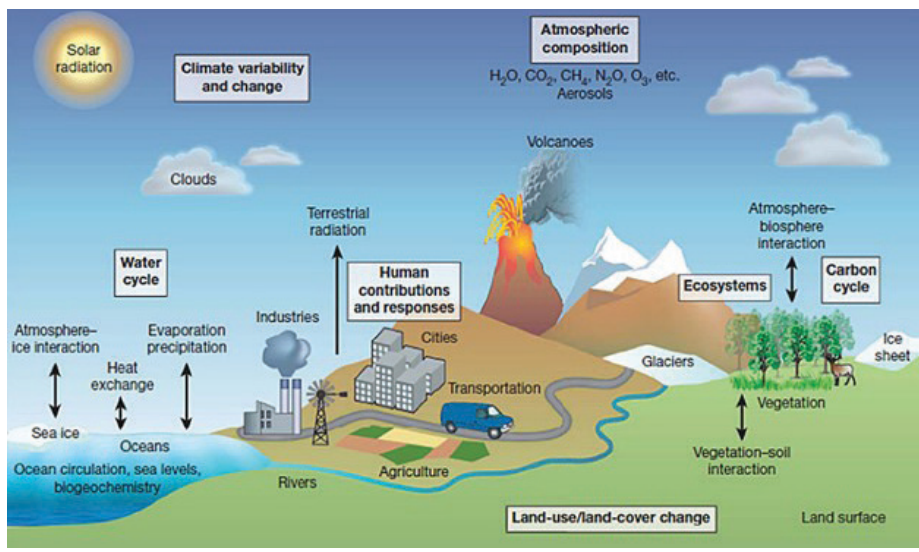

Figure 1. Natural and anthropogenic processes in the climate system. Credits: NOAA (2017)

Regions with similar climate are classified to understand climate variability at a global scale in agriculture, hydrology, geography, biology, education, and research (Figure 2; Table 1). One way to broadly characterize the climate of an area is often based on air temperature and rainfall amount. According to the Köppen-Geiger climate classification

1. This document is AE546, one of a series of the Department of Agricultural and Biological Engineering, UF/IFAS Extension. Original publication date November 2020. Visit the EDIS website at https://edis.ifas.ufl.edu for the currently supported version of this publication.

2. Young Gu Her, assistant professor, Department of Agricultural and Biological Engineering; Zachary Brym, assistant professor, Agronomy Department; Ashley Smyth, assistant professor, Department of Soil and Water Sciences; and Elias Bassil, assistant professor, Horticultural Sciences Department; UF/ IFAS Tropical Research and Education Center, Homestead, FL 33031.

The Institute of Food and Agricultural Sciences (IFAS) is an Equal Opportunity Institution authorized to provide research, educational information and other services

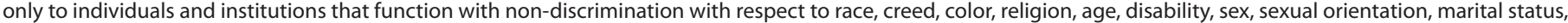

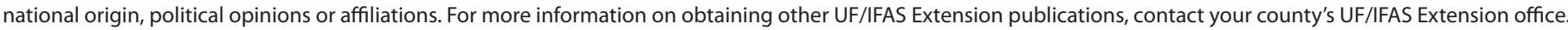
U.S. Department of Agriculture, UF/IFAS Extension Service, University of Florida, IFAS, Florida A \& M University Cooperative Extension Program, and Boards of County Commissioners Cooperating. Nick T. Place, dean for UF/IFAS Extension. 
scheme, most areas of Florida have a temperate climate without a dry season but with a hot summer (denoted as 'Cfa'; Peel et al. 2007). Three tropical climate zones are found in south Florida: tropical monsoon-north Miami to Port St. Lucie (Am); tropical rainforest-coastal areas along Fort Lauderdale to West Palm Beach (Af); and tropical savannah-the Everglades and coastal areas along Cape Coral to Naples (Aw) (Figure 2). In the tropical climate zone, the average air temperature of the coldest month is above $64^{\circ} \mathrm{F}$ $\left(18^{\circ} \mathrm{C}\right)$ (Table 1$)$, which makes south Florida one of the few places to grow tropical fruits and vegetables in the United States. The scientific classification can differ from the public perception of weather and climate depending on the spatial scales and the way terms are defined. For instance, a climate is regarded as "without a dry season" when the precipitation of the driest month is greater than a threshold defined at a global level (Table 1). However, "a dry season" may mean a period that has relatively less rainfall, such as October to April in Florida.

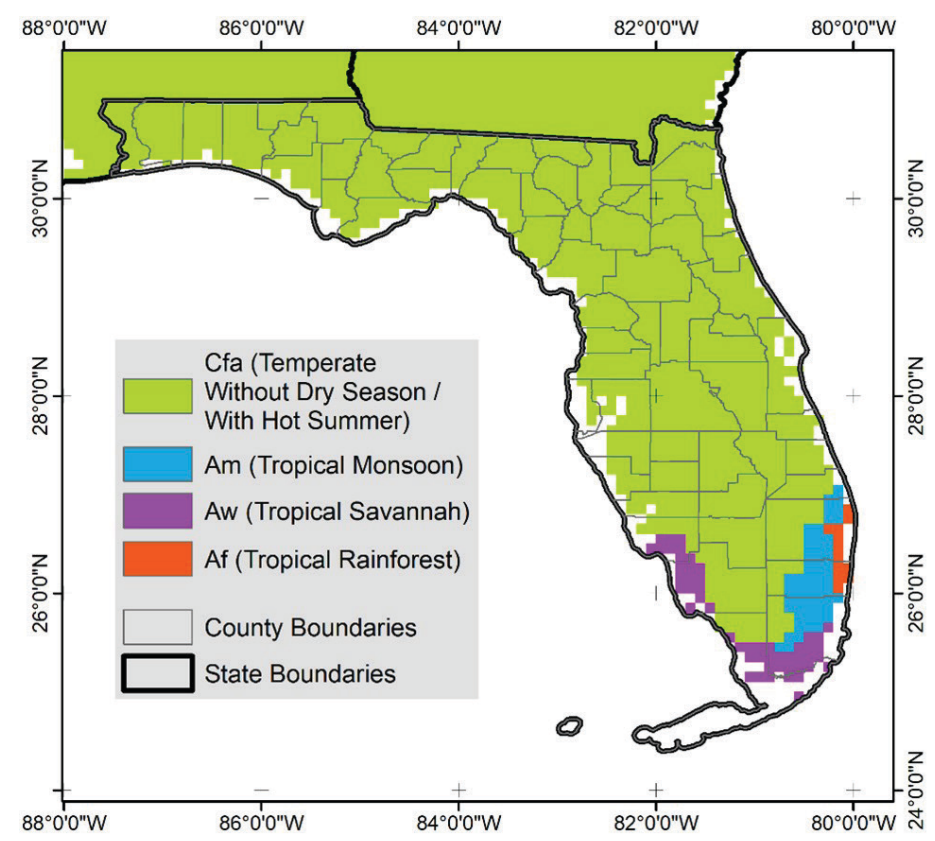

Figure 2. The Köppen-Geiger climate zones of Florida.

Credits: Recreated from Peel et al. (2017)

\section{What are climate models?}

Climate models are used to understand spatial and temporal patterns in climate variability. Climate models can also be used to make predictions about the future. A model is a representation of our understanding of reality that can be presented conceptually or in tangible form (i.e., scale model of a car, globe, or human body). Natural processes including air and water cycles are often too large in space to be represented in a tangible model. In such cases, mathematics becomes a useful tool to represent the understandings and ideas conceptually (Figure 3). Scientists use mathematical equations to describe how the climate system behaves based on scientific observations and findings. A climate model is a set of equations organized to simulate the relationship between the variables and climate forcings, such as changes in the average amount of solar energy absorbed and atmospheric greenhouse gas concentrations. Climate scientists and modelers use climate models to numerically describe (or simulate) meteorological processes and project future climate. Here, the terms "project" or "projection" are commonly used to clarify the fact that predictions are made using climate models based on the assumptions of future greenhouse gas emissions. An effective climate model takes into consideration all important variables, makes realistic assumptions, and reliably predicts climate outcomes before they occur. An excellent and detailed explanation of climate models can be found at https://www.carbonbrief.org/ qa-how-do-climate-models-work.

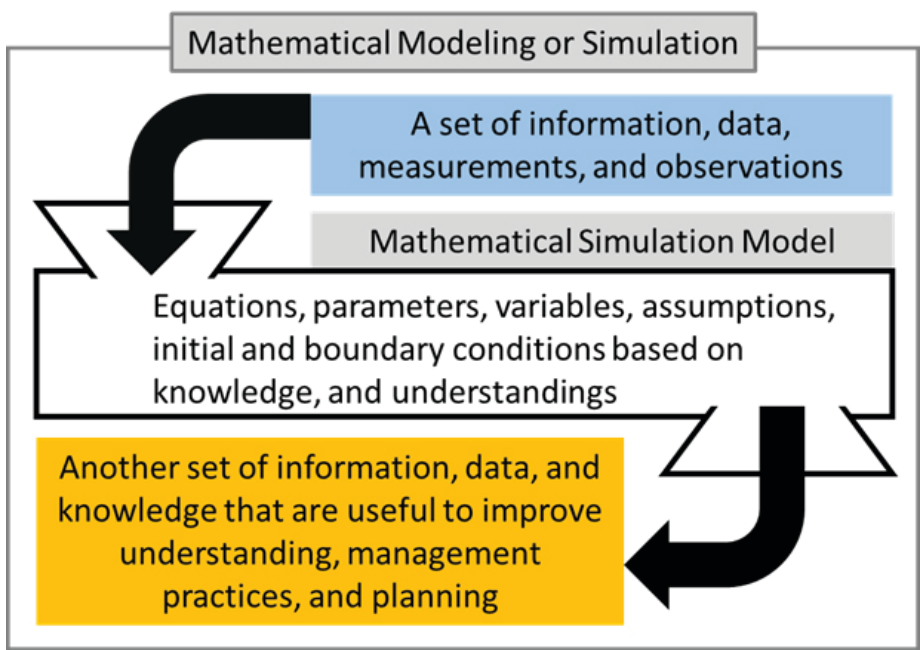

Figure 3. A schematic diagram of a mathematical simulation model, which climate models are.

Credits: Young Gu Her, UF/IFAS

\section{What are General (or Global) Circulation Models (GCMs)?}

A GCM is a type of climate simulation model that describes the flows of air, water, and heat around the globe. Climate parameters and variables in the model represent the motion of air and water in the atmosphere (Figure 4). The patterns of air and water circulation are generalized and described mathematically in GCMs. Figure 4 also illustrates the general circulation of the atmosphere. There are also Regional Climate Models (RCMs) used to simulate climate processes in more detail at smaller spatial scales (i.e., at a regional scale rather than a global one). GCMs cover the entire globe, and RCMs focus on a subset (a country, region, state, or even county) of the GCM coverage. 

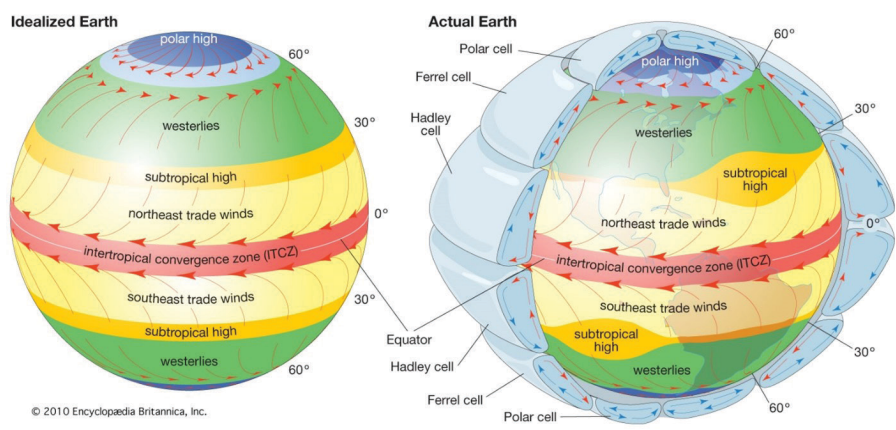

Figure 4. General atmospheric circulation patterns represented in climate models.

Credits: By courtesy of Encyclopædia Britannica, Inc., copyright 2015; used with permission.

Several national and international institutes make future climate projections using GCMs that were developed based on the current understanding of climate systems. Since 1995, the Working Group on Coupled Modelling (WGCM) of the World Climate Research Programme (WCRP) has implemented the Coupled Model Intercomparison Project (CMIP). The goal of CMIP is to obtain better understanding of future climate variability caused by natural and man-made factors by assessing the performance and uncertainty of future climate projections made by multiple climate models (WCRP 2017). The CMIP has expanded in parallel with the Intergovernmental Panel on Climate Change (IPCC) scientific assessment (IPCC 2017). The IPCC is the United Nations' body for regularly assessing the science related to climate change for policymakers (IPCC 2017). Now the CMIP and IPCC assessments are in their sixth phase (CMIP6) and assessment report cycle (AR6).

As climate models and GCMs represent our understanding of reality, their outputs can include deviations from the real state of the system at any given point in space or time. These deviations are represented in the model as uncertainty, which is formally expressed as the range of possible deviation. Climate modelers try to reduce deviation and uncertainty by incorporating additional observations, knowledge, computing resources, and analytical techniques into climate modeling. Differences in future climate projections made by climate models are attributable to differences in the conceptual understanding about climate systems that are incorporated into climate models. Such differences can be regarded as part of the uncertainty, but may also create improved models that lower uncertainty. Scientists often incorporate multiple models to make an ensemble projection that contributes to decision-making processes.

\section{What are Representative Concentration Pathways (RCPs)?}

There are many factors that affect climate. Greenhouse gas concentrations are a critical factor that strongly influences the long-term state of Earth's energy balance. Greenhouse gases affect climate by changing the amount of energy from the sun coming in and going out of the Earth's atmosphere. The high concentrations of greenhouse gases in the atmosphere are largely due to human activities, including the burning of fossil fuels. When more energy remains in the environment due to increased greenhouse gas concentrations, the Earth will warm. Earth's temperature generally remains consistent over the long term as the Earth's energy budget has been historically in balance. Radiative forcing, the term used to describe this energy balance, is expressed in watts per unit area (i.e., $\mathrm{W} / \mathrm{m}^{2}$ ). A watt is a unit of power, such as $60 \mathrm{~W} / \mathrm{m}^{2}$ of an incandescent light bulb and $10 \mathrm{~W} /$ $\mathrm{m}^{2}$ of a light-emitting diode (LED).

Climate scientists and modelers developed several climate scenarios related to greenhouse gas emission based on different expectations of how people and societies may respond to changing climate in the future. Four greenhouse gas concentration trajectories were adopted by the IPCC for its fifth Assessment Report (AR5) in 2014 (Gettelman and Rood 2016). The trajectories describe four possible climate scenarios depending on the amount of greenhouse gas emitted in the future, and each scenario is expressed in the unit $\left(\mathrm{W} / \mathrm{m}^{2}\right)$ of radiative forcing (or Earth's energy budget): RCP2.6, RCP4.5, RCP6.0, and RCP8.5 (Figure 5a). For instance, RCP4.5 represents a greenhouse gas concentration trajectory that reaches the radiative forcing of $4.5 \mathrm{~W} / \mathrm{m}^{2}$ in 2100 (Figure 6a). The radiative forcing of $4.5 \mathrm{~W} / \mathrm{m}^{2}$ means that the Earth receives the net energy gain of $4.5 \mathrm{~W}$ per its unit area $\left(\mathrm{m}^{2}\right)$, which is analogous to the situation where we have a bulb of $4.5 \mathrm{~W}$ in every square meter on the Earth's surface. The higher radiative forcing of the RCP scenario means more severe future global warming.

The radiative forcings can be interpreted by the corresponding carbon dioxide $\left(\mathrm{CO}_{2}\right)$ concentrations (Figure $5 \mathrm{~b}$ ). The current concentration of $\mathrm{CO}_{2}$ is around 400 parts per million (ppm), and the most pessimistic (or conservative) scenario (RCP8.5) says that it may reach around $950 \mathrm{ppm}$ by 2100 (Figure $6 \mathrm{~b}$ ). On the other hand, the most optimistic (or liberal) scenario (RCP2.6) projected that the wide use of bio-energy, carbon capture, and storage technologies (and reduced use of fossil fuels) might eventually decrease the $\mathrm{CO}_{2}$ concentrations in the late $21^{\text {st }}$ century. Details of the 
RCPs can be found in Moss et al. (2010) and van Vuuren et al. (2011).
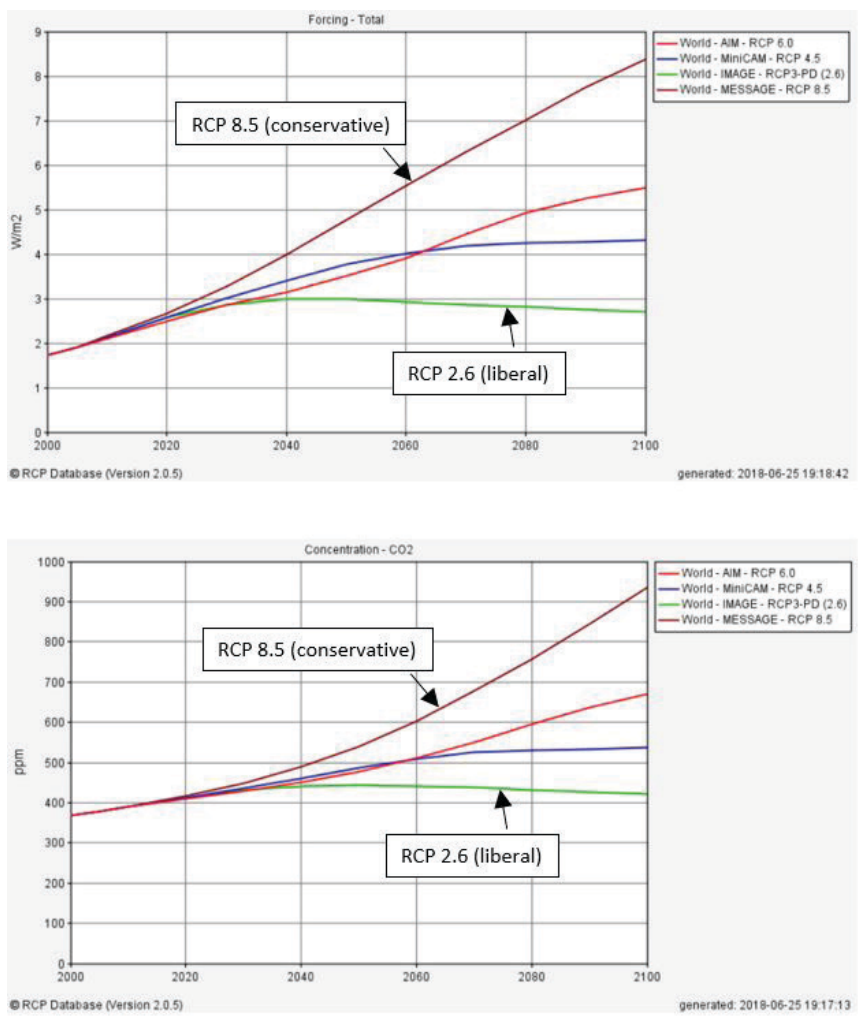

Figure 5. Radiative forcing and the corresponding $\mathrm{CO}_{2}$ concentration trajectories of the four RCPs: (a) radiative forcings and (b) $\mathrm{CO}_{2}$ concentrations (RCP Database 2018). The $x$-axes represent years, and the $y$-axes mean radiative forcings (a) and $\mathrm{CO}_{2}$ concentrations (b). Credits: RCP Database

\section{Summary}

Future climate is projected using our understanding of the physical processes affecting climate and the expected responses of our global society to progressing climate changes. Climate modeling is a scientific way to predict how the future climate may look. Projections are regularly updated with the latest physical and social information and with improvements to the models responding to advances in scientific understanding. Understanding regularly updated climate science is necessary when developing, advocating, and implementing viable measures and policies to mitigate and adapt to climate change impacts. This document provides information, including explanations about climate models, GCMs, and RCPs, to facilitate communication and discussion on climate changes and their impacts on our everyday life. Expected climate change impacts on plants and natural resources are discussed in a companion document.

\section{References}

Darby, M. 2015. “'Unreadable’ UN Science Reports Hampering Climate Action-Study." Accessed on August 24, 2020. http://www.climatechangenews.com/2015/10/12/ unreadable-un-science-reports-hampering-climate-actionstudy/

Encyclopædia Britannica. 2018. "Atmospheric Circulation." https://www.britannica.com/science/ atmospheric-circulation

Gettelman, A., and R. B. Rood. 2016. Demystifying Climate Models: A User Guide to Earth System Models. Springer-Verlag Berlin Heidelberg. https://doi. org/10.1007/978-3-662-48959-8

Harvey, C. 2015. "Climate change is getting worse-and UN climate reports are getting harder to understand." The Washington Post. Accessed on August 25, 2020. https:// www.washingtonpost.com/news/energy-environment/ $\mathrm{wp} / 2015 / 10 / 12 /$ even-as-climate-change-gets-worse-u-nclimate-reports-are-getting-harder-to-read/?utm_term=. faad24b66aa9

IPCC. 2017. "The Intergovernmental Panel on Climate Change." Accessed on August 25, 2020. http://www.ipcc.ch

Moss, R. H., J. A. Edmonds, K. A. Hibbard, M. R. Manning, S. K. Rose, D. P. Van Vuuren, T. R. Carter, S. Emori, M. Kainuma, T. Kram, and G. A. Meehl. 2010. "The Next Generation of Scenarios for Climate Change Research and Assessment." Nature 463 (7282): 747. https://doi. org/10.1038/nature08823

NASA. 2019. "What's the difference between weather and climate?" Accessed on August 25, 2020. https://www.nasa. gov/mission_pages/noaa-n/climate/climate_weather.html

National Research Council (NRC). 1982. "Solar, Astronomical, and Atmospheric Effects on Climate." In Climate in Earth History: Studies in Geophysics. Washington, D.C.: National Academies Press.

NOAA. 2017. "Geophysical Fluid Dynamics Laboratory: Earth System Models." Accessed on August 25, 2020. https://www.gfdl.noaa.gov/earth-system-model/

NOAA. 2019. "How is weather different from climate?" Accessed on August 25, 2020. https://www.noaa.gov/ explainers/what-s-difference-between-climate-and-weather 
Peel, M. C., B. L. Finlayson, and T. A. McMahon. 2007.

"Updated World Map of the Köppen-Geiger Climate Classification." Hydrology and Earth System Sciences Discussions 4 2): 439-473. https://doi.org/10.5194/hessd-4-439-2007

RCP Database. 2018. "RCP Database: Version 2.0.5.” Accessed on August 25, 2020. https://tntcat.iiasa.ac.at/RcpDb/ dsd? Action $=$ htmlpage $\&$ page $=$ compare

Van Vuuren, D.P., J. Edmonds, M. Kainuma, K. Riahi, A. Thomson, K. Hibbard, G. C. Hurtt, T. Kram, V. Krey, J. F. Lamarque, and T. Masui. 2011. "The Representative Concentration Pathways: An Overview." Climatic Change 109 (1-2): 5. https://doi.org/10.1007/s10584-011-0148-Z

WCRP. 2017. "WCRP Coupled Model Intercomparison Project (CMIP)." Accessed on August 25, 2020. https:// www.wcrp-climate.org/wgcm-cmip

Table 1. Descriptions of the Köppen-Geiger climate classes for Florida (Peel et al. 2017).

\begin{tabular}{|c|c|c|c|c|}
\hline 1st Symbol & 2nd Symbol & 3rd Symbol & Areas & Criteria \\
\hline $\begin{array}{l}\text { C } \\
\text { Temperate }\end{array}$ & $\begin{array}{l}\text { W } \\
\text { Without dry } \\
\text { season }\end{array}$ & $\begin{array}{l}\text { a } \\
\text { With } \\
\text { hot summer }\end{array}$ & Most of Florida & $\begin{array}{l}\text { - The air temperature of the hottest month is between } 50^{\circ} \mathrm{F}\left(10^{\circ} \mathrm{C}\right) \\
\text { and } 72^{\circ} \mathrm{F}\left(22^{\circ} \mathrm{C}\right) \text {, and } \\
\text { - The air temperature of the coldest month is less than } 64^{\circ} \mathrm{F}\left(18^{\circ} \mathrm{C}\right) \text {, } \\
\text { and } \\
\text { - The precipitation of the driest month in summer is greater than } \\
1.57 \text { inches }(40 \mathrm{~mm}) \text { or greater than one-third of the precipitation } \\
\text { of the wettest month in winter, or } \\
\text { - The precipitation of the driest month in winter is greater than } \\
\text { one-tenth of the precipitation of the wettest month in summer. }\end{array}$ \\
\hline $\begin{array}{l}\text { A } \\
\text { Tropical }\end{array}$ & $\begin{array}{l}\mathrm{f} \\
\text { Rainforest }\end{array}$ & - & $\begin{array}{l}\text { South Florida } \\
\text { (east) }\end{array}$ & $\begin{array}{l}\text { - The air temperature of the coldest month is greater than } 64^{\circ} \mathrm{F} \\
\left(18^{\circ} \mathrm{C}\right) \text {, and } \\
\text { - The precipitation of the driest month is greater than } 2.36 \text { inches } \\
(60 \mathrm{~mm}) \text {. }\end{array}$ \\
\hline $\begin{array}{l}\text { A } \\
\text { Tropical }\end{array}$ & $\begin{array}{l}\mathrm{m} \\
\text { Monsoon }\end{array}$ & - & $\begin{array}{l}\text { South Florida } \\
\text { (east) }\end{array}$ & $\begin{array}{l}\text { - The air temperature of the coldest month is greater than } 64^{\circ} \mathrm{F} \\
\left(18^{\circ} \mathrm{C}\right) \text {, and } \\
\text { - The precipitation of the driest month is less than } 2.36 \text { inches } \\
(60 \mathrm{~mm}) \text { and greater than } 100 \text { minus } 4 \% \text { of mean annual } \\
\text { precipitation. }\end{array}$ \\
\hline $\begin{array}{l}\text { A } \\
\text { Tropical }\end{array}$ & $\begin{array}{l}\text { W } \\
\text { Savannah }\end{array}$ & - & $\begin{array}{l}\text { South Florida } \\
\text { (south and } \\
\text { west) }\end{array}$ & $\begin{array}{l}\text { - The air temperature of the coldest month is greater than } 64^{\circ} \mathrm{F} \\
\left(18^{\circ} \mathrm{C}\right) \text {, and } \\
\text { - The precipitation of the driest month is less than } 2.36 \text { inches }(60 \\
\mathrm{mm}) \text { and less than } 100 \text { minus } 4 \% \text { of mean annual precipitation. }\end{array}$ \\
\hline
\end{tabular}

